\title{
Using Career Education to Help Students Build and Articulate Employability Skills
}

\author{
Lynda Peto \\ University of Manitoba \\ Lynda.Peto@umaniotba.ca \\ Carolyn Geddert P. Eng. \\ University of Manitoba \\ Carolyn_Geddert@umanitoba.ca
}

\begin{abstract}
For $80 \%$ of first-year students, the highest motivators for attending University are related to getting a good job and preparing for a career. Research has shown that post-secondary students with some career goals and engaged in career development experiences have higher levels of engagement, academic performance, mental health, and persistence. Employers are placing a greater emphasis on a student's skills and experience in their recruitment process. No longer does a University degree guarantee employment success upon graduation.

Career education can provide the foundation and framework to help students make these connections and be successful in transitioning into the world of work. By understanding what employers' value and knowing how to build and gain skills and experiences while in University, students can enhance their employability outcomes and successfully launch into their career upon graduation.
\end{abstract}

The Faculty of Engineering along with Career Services at the University of Manitoba, have developed an innovative partnership to deliver career education embedded in required 1st and 2nd year Engineering courses. The program called "Your Career Starts Here" was introduced in the Fall 2013 term in Design in Engineering (Eng 1430) and Technical Communications (Eng 2010) courses. The learning outcomes of these interactive modules for students include: recognizing career development as a life-long process of learning; identifying and describing employability skills; identifying what employers value in the recruitment process; matching skills with an employer's needs as well as identifying gaps; and reflecting on opportunities at University to build, enhance and develop skills and experiences. Academic courses, work experiences, cooperative education and internship programs, research experiences, and involvement in campus groups and cocurricular programming are identified as career development opportunities at the University of Manitoba. The modules include group discussions and activities to help students understand and identify ways to build their skills and experiences as well as how to articulate these skills to increase their employability outcomes upon graduation.

Keywords: Career, Employability, Skills

\section{INTRODUCTION}

Career Development is defined "as the process of managing learning, work, leisure and transitions in order to move towards a personally determined and evolving future for both public and private good"(Patton \& McMahon, (2004)). Students attending the University of Manitoba have an opportunity to engage in career development activities that will give them skills and experiences and enhance their employability skills. "Your Career Starts Here" program is a series of modules proposed to be embedded in existing courses offered in the Faculty of Engineering. The reason that these modules are embedded in curriculum is based on best practices and supported by Wiggers \& Arnold (2011) who state that students who are in most need of additional support are the least likely to seek support. With modules embedded in existing curriculum, this program will support student's understanding of their own career and employability skills development while they are a student in the Faculty of Engineering.

\section{PROPOSED LEARNING MODULES}

\subsection{Module \#1 - Identifying Skills and Building Competencies through Academic, Experiential, and Co-curricular activities}

This introductory module is provided in the first class of the first year design course. It is deliberately inserted at the beginning of the term to frame the course learning 
outcomes and encourage student's involvement in experiential and co-curricular activities in the faculty. Students are provided the opportunities to reflect, share and discuss with other students throughout the workshop.

Mackeracher (2004) states that "learning is facilitated when the learning activities provide opportunities to talk about and share experiences: (p.38). The anticipated outcomes of this module include;

- Understand the concept of Career Development as a foundation for life long learning and career success.

- Understand employability Skills and be able to reflect on the employability skills found in course curriculum.

- Identify other opportunities outside of academic courses that build employability skills.

\subsection{Module \#2 - Marketing Yourself for Employment Success}

These modules are focused on helping students identify the needs of employers and being able to articulate their skills and experiences that match with an employer's needs. Students are encouraged to reflect on academic, experiential, co-curricular, volunteering, summer and part-time work experiences and relating them to what employers value and need. Employers are looking for more than degrees. They are also looking for what skills and experiences that students can contribute and demonstrate in their workplace (Lowden, Hall, Elliot \& Lewin, 2011)

\subsubsection{Resumes with Results}

This module is offered as part of the second year Technical Communication or Design Trilogy courses. The learning outcomes of this module include the following;

- Identify styles of resumes and critically analyze their effectiveness in marketing employability skills.

- Identify employer's needs by analyzing job postings and other resources

- Reflect and identify personal employability skills and identify gaps from employers needs.

- Identify and write demonstration statements.

\subsubsection{Job Search and Networking}

This module may be offered as part of the final year Capstone Design courses and has been offered as part of a co-curricular activity. The learning outcomes for this module include;

- Develop and practice personal marketing statements.
- Develop confidence in networking and connecting with employers.

- Explore and expand knowledge of employers in industry.

- Understand in-person and on-line strategies used in the job search process.

\section{CONNECTING GRADUATE ATTRIBUTES TO EMPLOYABILITY SKILLS}

The course objectives of the first year design class lend themselves to connecting employability skills with CEAB Graduate Attributes. The objectives of the course are to introduce students to fundamental concepts of the Engineering Profession. Professional behavior and communication are practiced in a team setting. Some of this practice includes role playing where students interact with a "boss" and "team mates" This interaction provides opportunities to practice behavior and develop attitudes that are both defined as a requirement by the CEAB graduate attributes and considered as key employability skills by industry groups such as the Conference Board of Canada.

\subsection{Employability Skills as defined by the Conference Board of Canada}

The Conference Board of Canada is well recognized for their economic and labor market research and helping guide Canadian industry and society to be dynamic and competitive, both nationally and internationally. Their Employability Skills 2000+ document is widely used in helping students identify "the skills you need to enter, stay in, and progress in the world of work- whether you work on your own or as part of a team" and this includes "employability skills, attitudes, and behaviors that employees need to participate and progress in today's dynamic world of work" (Conference Board of Canada, 2000).

\subsection{Graduate Attribute outcomes for the First Years Design course}

Module \#1 is presented to students in course \# ENG1430 - Introduction to Engineering Design. This course is required for graduation and is typically included in some of the first courses students will study within the faculty. The course outline details the learning outcomes as they relate to the Graduate Attributes that are included in ENG1430 and the expected competency level at completion of the course. (See Appendix A). Students are asked to review these learning outcomes in light of the 
employability skills they have discovered and documented in their review of the Conference Board of Canada Employability Skills. At the conclusion of this session students are encouraged to name the employability skill training they will receive in the course and how it will be practiced. They are also asked to suggest co-curricular, experiential, and other work experiences that might provide additional opportunities related to enhancing employability and/or enhancing competency in the Graduate Attributes as they relate to the course.

\subsection{Continued influence in the Technical Communications, design trilogy and Capstone Design Courses}

The development and articulation of skills and experiences are explored further in ENG2010 using Module \#2 and potentially the Capstone Design Course. Students are encouraged to critically analyze and reflect on their own employability skills and experiences that they have gained and developed as they prepare to graduate. The modules include role playing exercises, practice, feedback, and peer evaluation to assist students in marketing, articulating, and practicing their skills for employment success upon graduation.

\section{CO-CURRICULAR SUPPORTS}

The modules reinforce for students that they should consider opportunities to practice and improve their employability skills by increasing their co-curricular involvement. The faculty of Engineering at the University of Manitoba has facilitated many such opportunities to help students also practice and improve their Graduate Attributes. It has been key for the faculty to partner with students and industry to provide these opportunities for all students.

\subsection{Student Led Competition teams}

Student led teams provide the opportunity work on real projects as part of a real team. The design requirements are demanding and the design review is extensive. Teams function within a budget and need to provide project management to get the project completed with in the required timeline. Employers consistently look for these types of experiences when recruiting students.

Industry and faculty support competition team opportunities for students in all departments and programs. These include the SAE (formerly the Society of Automotive Engineers) formula, baja, electric vehicle and Aero teams, the Quarter Scale Tractor team, the Steel Bridge, Concrete Toboggan Team and the Satellite
Design Team. All these team face the rigor of an international competition.

\subsection{Helping Industry Reach Engineering students Directly (H.I.R.E.D.)}

In an effort to connect Engineering Students with the diverse engineering community in Manitoba, The University of Manitoba Engineering Society (UMES) and the faculty have collaborated and organized a regular weekly meeting. The meeting is scheduled every Monday night at 5:30 through the fall and winter academic terms. This regularity allows students to plan their weekly schedule to accommodate attendance. The presentations are most commonly made by industry partners who wish to highlight opportunities for engineering students and graduates with in their company or industry. This time has also been used to present information about the Engineering community in Manitoba generally, provided opportunities for networking or even special presentations on topics in workplace safety or ethics.

Attendance at these events is made to be very convenient for students. The event is at 5:30 PM every Monday. This coincides with the end of most classes or labs for the day. The event always includes a meal for the students. These deliberate arrangements have resulted in an average attendance of approximately 100 students. The UMES has promoted this event to the student population as vital to their professional development and encourages all students to attend.

\subsection{Reverse Career Fair}

Role-playing has been a valuable tool for students to practice their employability skills and improve a graduate attribute. The reverse career fair provides an opportunity to practice oral, visual and written communication as students market themselves to employers. The event is set up as students prepare "booths" around a large conference room.

Most recently this was done with approximately 100 students setting up in a large multipurpose room. The students prepared posters, brochures and table displays to market themselves. Employers spent the evening rotating through the room engaging with the students in conversation about their education and experiences. The evening provided students the opportunity to present themselves many times throughout the evening with passive and/or direct feed back to self-correct and improve. It was a unique opportunity to improve communication skills in real time. 


\subsection{Industry Support}

The Faculty of Engineering at the University of Manitoba partner with a unique group of top engineering industry leaders who share the Faculty's commitment to excellence in engineering education. This organization is known as Friends of Engineering Manitoba. The Friends have supported the Faculties programs and co-curricular activities. This support has provided students and faculty with feedback that facilitates the understanding of the Graduate attributes from an engineering employer's perspective. The Friends have supported the faculty with financial support for co-curricular activities such as H.I.R.E.D and the reverse career fair. They have offered targeted scholarships and awards that reward students for academic performances that focus on the graduate attributes they value most. They support the student competition teams and celebrate their achievements. The Friends include members of the Faculty administration and staff on their executive board in order to maintain regular and meaningful communication on the "job readiness" of University of Manitoba Engineering Graduates in terms of the CEAB Graduate Attributes.

In a similar manner The Aerospace industry sector has established its own industry liaison group. This Manitoba Aerospace Engineering Liaison group (MAELG), has quarterly meetings to offer industry advice on a range of issues including the skills needed for Engineering Graduates to be successful in industry. MAELG provides financial assistance and supports industry volunteers to mentor students and student groups. This industry support is valuable as The Faculty works to ensure it provides excellent academic and co-curricular learning opportunities for engineering students.

\section{Experiential Education}

\subsection{Co-operative Education}

The Co-operative Education and Industrial Internship Program (Co-op/IIP) in the Faculty of Engineering at the University of Manitoba is available to all engineering students in good academic standing. The number of students in Co-op/IIP has doubled since 2011. This is a result of the program becoming a highlighted cocurricular activity to improve and practice the employability skills that are included in their traditional academic education. Co-op/IIP is directed by an Engineer-in-Residence. Input from industry groups, Friends of Engineering and MAELG for example, have led to changes and improvements in the program to provide students with more opportunities to practice evaluate and improve their employability skills. At the completion of each four month work term the students have an opportunity to reflect on their experience. They document their successes and where they continue to need practice and improvement. Employers also reflect on the student performance and complete a survey that allows them to reflect directly on a student's CEAB graduate attributes. This data is analyzed and the results are available for Faculty and Administration to review.

\subsection{Community Service}

Students are exposed to many co-curricular opportunities during the first year design course (ENG 1430 ) at the University of Manitoba. Included in these is the concept that the opportunity for community involvement is beneficial to both the community and the students. Students are presented with the idea that the professionalism required of Professional Engineers requires a commitment to serve the community and that they gain both employability skills and improve their graduate attributes when they participate.

The University of Manitoba Engineering Society (UMES) community involvement committee offers two major opportunities for students to support the community. The opportunities coincide with the academic terms. Students are encouraged to participate in these fundraisers by accepting or purchasing whipped cream pies in the face. The students all have a pie in the face ordered for them to receive and can purchase pies for the instructors to receive. This puts the student in a position to put the needs of the community ahead of themselves. They also have the opportunity to see their Instructors and Teaching Assistants accept this responsibility and accept multiple pies in the face to support a community cause or charity. This is only a brief introduction to the benefit of supporting the community and understanding that as they progress in their career community service will connect them to the community they will serve as professionals.

\subsection{Conclusion}

Over the last 3 years, research has shown that more and more students place career and employment related issues as the single most important reason for attending university (Canadian University Survey, 2013). The Faculty of Engineering at the University of Manitoba has embedded career education into their curriculum and cocurricular activities to meet the student's needs and importance placed on career development. Many of these skills are also reflected in the CEAB Graduate Attributes as well. Through innovative academic and co-curricular programming, students are able to identify, develop and articulate their employability skills, to help prepare for a successful career transition upon graduation.

\section{Acknowledgements}

We would like to acknowledge Dr. Douglas Ruth, NSERC Design Chair, University of Manitoba for 
financial support of this initiative. We would like to thank the following Academic Staff for their partnership on this project; Mr D. Petkau, Dr J. Paliwal, Dr J. Morrison, Dr A. Parker, and Dr S. Ingram. We would also like to acknowledge Megan Johnson, Co-op/IIP Administrator, Amber Skrabek, Executive Director, Friends of Engineering, Ben Marriot, 2013/14 Senior Stick, University of Manitoba Engineering Society and Jill Seniuk Cicek.

\section{References}

Canadian University Survey Consortium "CUSC

2013 first-year student survey: Master report". Prairie Research Associates, 2013, pp30-36. Available as of April 2014 from : http://www.cuscccreu.ca/publications/2013 CUSC FirstYear master\%20re port.pdf

Conference Board of Canada. (2000). Employability Skills 2000+ Framework. Retrieved from: http://www.conferenceboard.ca/Libraries/EDUC PUBL IC/esp2000.sflb
Lowden, K., Hall, S., Elliot, D., \& Lewin, J. (2011). Employer's perceptions of the employability skills of new graduates. In London, England: Edge Foundation 2011. Retrieved from:www.edge.co.uk/media/63412/employability skill s as pdf - final online version.pdf

MacKeracher, D.,(2004) Making Sense of Adult Learning. (2nd ed.)Toronto: University of Toronto Press

McMahon, M., Patton, W., \& Tatham, P. (2003). Managinglife, learning and work in the 21st century: Issues informing the design of an Australian blueprint for career development. Miles, Morgan Australia Pty Ltd.

Wiggers, R. \& Arnold, C. (2011). "Defining, Measuring and Achieving "Student Success" in Ontario Colleges and Universities." Higher Education Quality Council of Ontario, Issue paper No.10, p.17, August 2011. 
Proc. 2014 Canadian Engineering Education Association (CEEA14) Conf.

\section{APPENDIX A: ENG 1430 Course Description/Objectives}




\section{Course Description/Objectives}

\section{Undergraduate Calendar Description}

The Creative Process; The Design Process; Working in a Team. The Engineering Profession from the Perspective of Students and Professionals. Academic, Legal and Ethical considerations.

\section{Instructional Methods}

This course is "team taught" to reflect the degree of team learning the students are expected to undertake. Lectures will be delivered by one of the instructional team members. The majority of the course will be spent on design projects ("laboratory hours"). The laboratory hours will have the instructional team present to provide assistance, team decision-making and ensure consistency.

\section{Course Objectives}

The objective of this course is to create a fundamental understanding of the Engineering profession and provide students with an extended experience working in a creative engineering design team environment. Students will become familiar with the engineering design approach and the incorporation of creative processes within that approach. By accepting collective responsibility for the functioning of their design teams, students will better understand the problems and benefits of working in this sort of environment. We will also introduce the concepts of professionalism and consider the ways professionals apply their technical expertise.

\section{Learning Outcomes}

At the conclusion of this course, the student should be able to:

1. Demonstrate concepts of professionalism as they relate to the profession of Engineering.

2. Comprehend basic concepts of safety and failure in engineering design.

3. Apply principles of teamwork in a design team setting.

4. Apply principles of project management to the completion of an open-ended design problem.

5. Apply principles of project documentation (engineering journals, meeting minutes, report writing).

6. Use the engineering design approach to solve open-ended problems.

\section{Expected Competency Level **}

\begin{tabular}{|c|c|c|c|c|c|c|c|c|c|c|c|c|}
\hline $\begin{array}{c}\text { Learning } \\
\text { Outcome }\end{array}$ & A1 & A2 & A3 & A4 & A5 & A6 & A7 & A8 & A9 & A10 & A11 & A12 \\
\hline 1 & & & & & & & & 3 & & & & \\
\hline 2 & & & & & & & & 2 & 2 & & & \\
\hline 3 & & & & & & 3 & 3 & & & & & \\
\hline 4 & & & & & 3 & & & & & & 3 & \\
\hline 5 & & & & & & & 3 & & & & & \\
\hline 6 & & & & 5 & & & & & & & & \\
\hline
\end{tabular}

\section{*Attributes:}

A1 A knowledge base for engineering

A2 Problem analysis

A3 Investigation

A4 Design

A5 Use of engineering tools

A6 Individual and team work

A7 Communication skills

A8 Professionalism

A9 Impact of engineering on society/ environment

A10 Ethics and equity

A11 Economics and project management

A12 Life-long learning
${ }^{* *}$ Competency Levels:

1 - Knowledge (Able to recall information)

2 - Comprehension (Able to rephrase information)

3 - Application (Able to apply knowledge in a new situation)

4 - Analysis (Able to break problem into its components and establish relationships)

5 - Synthesis (Able to combine separate elements into whole)

6 - Evaluation (Able to judge of the worth of something) 